\title{
SEBUAH PELAJARAN DARI PELAKSANAAN REFORMASI PAJAK DI INDONESIA DAN VIETNAM
}

\section{A LESSON FROM IMPLEMENTATION OF TAX REFORMS IN INDONESIA AND VIETNAM}

\author{
Abdul Rahman \\ Lecturer at STIA LAN Bandung \\ Cimandiri Street 34 - 38 Bandung \\ e-mail: rhnoke@yahoo.com
}

Article received: 6 April 2017, Revised: 29 April 2017, Approved: 30 April 2017.

\begin{abstract}
1997 Asian crisis brought ASEAN countries in condition where banking system damaged, GDP dropped and the exchange rate plunged. Taxation became 'rescuer' to overcome financial deficit and stable economy. Improvements in taxation are realized by tax reforms. In ASEAN, tax reforms have been undertaken since 1980s and they have significant contribution to increase tax revenue and to improve tax ratio. Specifically, we highlight Vietnam as the highest ratio and Indonesia as the lowest ratio. This paper explores the elements of innovation in tax reforms between Indonesia and Vietnam in order to seek the key of success factor of Vietnam in tax ratio. Our study found several interesting points. Firstly, tax reforms in Indonesia and Vietnam have similarity approaches, namely focusing on the policy and administration reforms. Secondly, for both countries, tax reforms have contributed in increasing tax revenue. Thirdly both countries highlight the role of tax reforms in enlarging the function of government in allocating state budget for social expenditure. Finally, we underscore the appreciation of government for society as taxpayers in the form of large allocation for public interests as a key success factor in increasing tax ratio in Vietnam,
\end{abstract}

Keywords: tax reforms, phase of reforms, lesson of reform, tax revenue, tax ratio

\begin{abstract}
Abstrak
Krisis di Asia pada tahun 1997 telah membawa negara-negara di ASEAN pada kondisi di mana sistem perbankan rusak, PDB turun dan nilai tukar mata uang jatuh. Perpajakan datang sebagai penyelamat untuk mengatasi krisis keuangan dan membuat perekonomian menjadi stabil. Perbaikan-perbaikan di sektor pajak diwujudkan melalui reformasi perpajakan. Di ASEAN, reformasi perpajakan telah dilaksanakan sejak tahun 1980 dan secara signifikan memberikan kontribusi untuk meningkatkan penerimaan pajak dan memperbaiki rasio pajak. Secara spesifik kami menggarisbawahi Vietnam sebagai negara dengan rasio pajak tertinggi dan Indonesia dengan rasio pajak terendah. Paper ini menggali
\end{abstract}


elemen-elemen inovasi pada reformasi pajak di antara Indonesia dan Vietnam untuk mencari factor kunci kesuksesan rasio pajak di Vietnam. Studi kami menemukan beberapa poin penting. Pertama, reformasi pajak di Indonesia dan Vietnam mempunyai pendekatan yang sama yaitu fokus terhadap reformasi kebijakan dan administrasi. Kedua, bagi kedua negara, reformasi pajak telah berperandalam meningkatkan penerimaan pajak. Ketiga, kedua negara menggarisbawahi peran reformasi pajak dalam meningkatkan fungsi negara dalam pengalokasian keuangan negara untuk pengeluaran sosial. Terakhir, kami mencatat penghargaan pemerintah terhadap masyarakat sebagai pembayar pajak dalam bentuk alokasi dana yang besar untuk kepentingan masyarakat sebagai faktor kunci kesuksesan peningkatan rasio pajak di Vietnam.

Kata kunci: reformasi pajak, tahapan reformasi, pelajaran dari reformasi, penerimaan pajak, rasio pajak

\section{A. INTRODUCTION}

The 1997 Asian crisis placed ASEAN countries into deep economic recession, in which the GDP dropped, the exchange rate plunged deeper, and the banking system was damaged. The crisis certainly has also bad impact on tax revenues, as the purchasing parity power of the society had decreased and some corporate taxpayers had liquidity or even solvency problem since the real value of their debt was in foreign currency denomination (Rizal 2008). Fortunately, taxation plays an active role in overcoming financial crisis and becomes a tool to make stable economy because it provides the easier and more obvious result in the collection process. For these reasons, countries worldwide pay serious attention to improve tax system including ASEAN through reforms of tax system.

Tax reforms in ASEAN countries (Indonesia, Vietnam, Malaysia, Singapore, Thailand, and Philippines) are performed since 1980s mainly to improve tax administration and tax revenue. In detail, the elements are separately namely modernizing the tax administration, simplifying tax laws, establishing an organizational structure based on the function, rationalizing tax rates by considering inflation and global economic crisis, determining the progressive tariff for income tax, accomplishing the efficiency and assessment program based on performance for tax administration, enlarging the indirect tax role such as the VAT by determining more precise and single tariff

Furthermore, programs of intensifying tax revenue are carried out by introducing the selfassessment system and some new taxes, improving control functions, reducing loopholes, exemptions, various allowances, and changing tax tariffs. In addition, law enforcement program by improving tax sanction is directed to find a good balance between preventive measures that promote voluntary compliance \& corrective measure and to fight against tax fraud and tax evasion. The government also conducted actively integrity improvement program to grow public trust so that voluntary compliance will increase positively (Mansfield 1987; Gillis 1989;Burgess and Stern 1993; Laurence 1999; Toye 2000; Islam 2001; Bird 2004, Bernardi et al.2005; Shome 2006).

As a result, these elements succeed in contribution to increase tax revenue and they lead ASEAN countries into the condition in which the capability of government to collect taxes or tax ratio at around 19 percent. In specific, comparison of tax ratio among ASEAN can be presented in the following figure: 


\section{Figure 1.}

Comparison of tax ratio between Indonesia \& ASEAN FY 1996-2014 and rank of total tax payment of ASEAN countries FY 2014

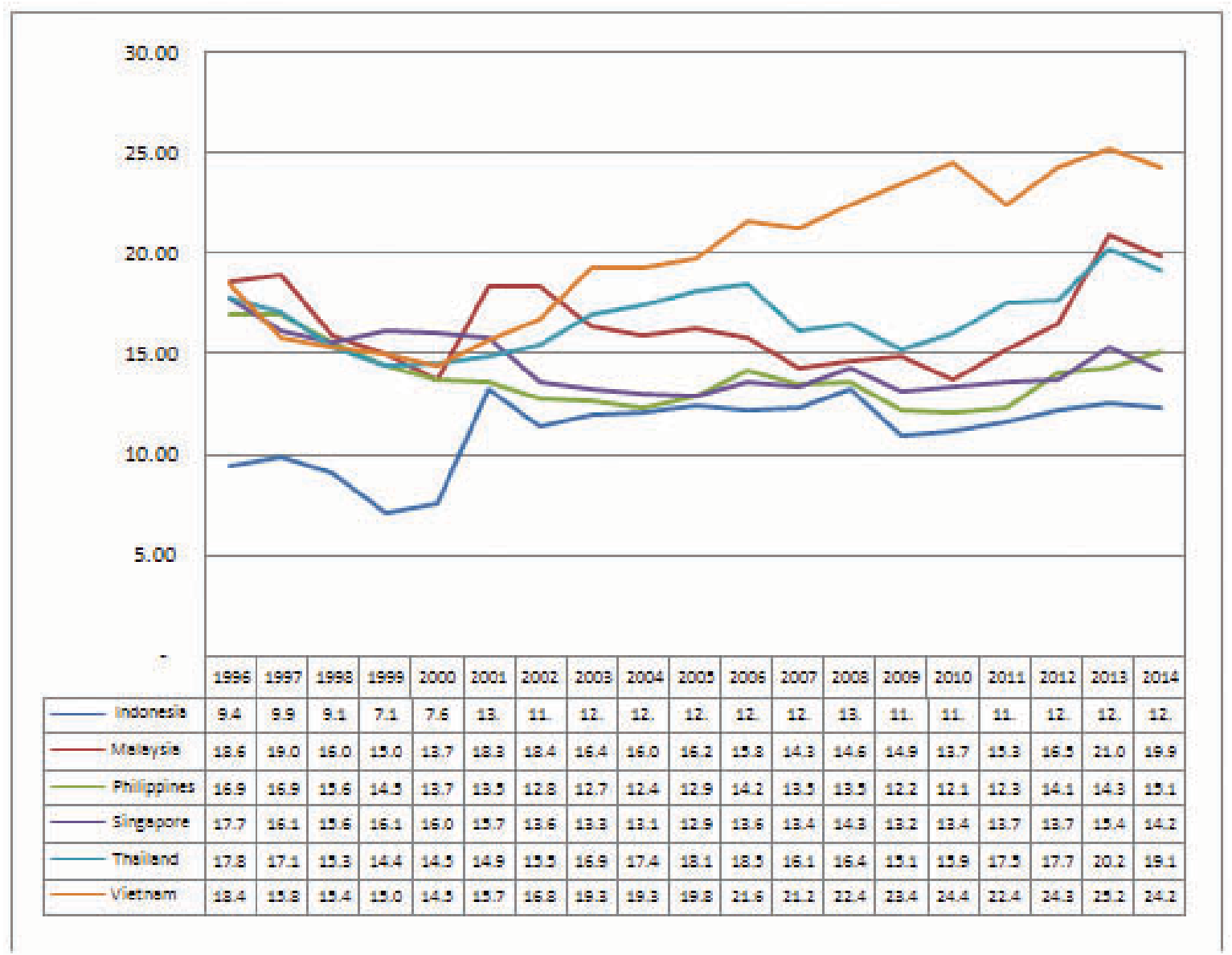

Source: Author’s compilation from IMF Report (2001) and OECD report (1996-2014)

Figure 1 shows that tax ratios in ASEAN from 1996 tend to increase slightly, to fluctuate, and to be stable for some countries. This figure also reveals Vietnam as the highest ratio and Indonesia as the lowest ratio. The difference of tax ratio between these countries is too far, at almost double in 2014. This condition invites our interest to find out the innovations undertaken in tax reforms between Indonesia and Vietnam in order to seek a key factor of success of Vietnam in tax ratio. The research question developed in this study is:

\section{What innovations have Indonesia and Vietnam performed in tax reforms and what insight can be learned to find the key factor the success of Vietnam in tax ratio?}

We aim to investigate the elements of tax reforms in Indonesia and Vietnam by identifying kind of innovations and to find the key factor of success of Vietnam in tax ratio based on the lesson learned from the reforms. Therefore, to answer this question, the study comprises four parts. In the second part, we discuss theoretical foundation about tax reform and related research in developing countries. Next, we present findings and discussion of results. Finally, we highlight the conclusion of our study and propose a further study as a recommendation. 


\section{B. RESEARCH METHOD}

This study is a descriptive qualitative method by using library research based on the written data from documents, books, journals, and others supported the research. The analysis is applied by developing data and describing them comprehensively and detail in line with the subject. In this context, I collected data regarding the implementation of tax reforms both in Indonesia and in Vietnam. I found the detail about tax reforms in Indonesia based on the paper from Abimanyu (2003), Arifin (2016), Bawazier (2011), Ikhsan et al (2005), Kiswara (2006), Nasucha (2004), Pandiangan (2008), Rizal (2008), Silaban (2010), and Uppal (2003). On the other hand, I captured specifically insights associated with tax reforms in Vietnam referred to papers from Chan (1999), Duc, Nguyen Cao and Yamaha (2009), Gilis (1989), Laurence (1999), Mansfield (1987), Mundle (1988), Mundle (1989), Norregaard (2015), Quang (1997), and Shukla et al (2011). According to these papers, I attained the real conditions about tax reforms in Indonesia and in Vietnam, and then I highlighted the lessons from the subject.

For analysis data, I used the comparative method. The step for this method was initiated firstly by conducting the study of documentation. In this step, I collected all related documents regarding tax reforms in Indonesia and Vietnam from national and international journals and books including report from directorate general of taxes and World Bank.Secondly, I completed the main data with some theories from Alm (1996) about the optimal tax system, Bird (2004) regarding administrative dimensions of tax reforms, and Gill (2003) about administration reform.

Furthermore, Data collected was analyzed by comparing the application and result of tax reforms in Indonesia and in Vietnam. In this context, I seek the similarities of implementation of both tax reforms in Indonesia and Vietnam. Finally, I highlighted the lessons from each country and I revealed a key factor of success in implementation of tax reforms. At least, overall results become the foundation for government in formulating appropriate tax reforms based on the Indonesia conditions.

\section{LITERATURE REVIEW}

\section{Tax reform}

Tax reforms derive from the fact that government need to implement certain public functions. Tax reform is a change from the existing tax structure and it has been chosen by the government since 1980s. One strong motivation behind the tax reforms, as a part of the public administration reform, is the reform can bring simplicity in the tax system by promoting equity, and efficiency (Feldstein 1976; McLure 1990). Therefore, tax reform conveys major change for all tax aspects and becomes a recipe for economic recovery. Tax reforms are also expected to achieve a high level of voluntary compliance, a high confidence on the tax administration, and a high productivity of the tax authorities through changing tax policy and the tax structure (tax base and tax rate), improving tax administration by building the good manager team, skilled staff training or retraining, \& the tax administration computerization according to the international standard, and reducing tax avoidance and tax evasion (Tanzi 1992;Perry and Whalley 1995;Mas’oed 1994;Alm 1996; Abimanyu 2003; Nasucha 2004).

The existence of public administration reform drives countries worldwide to deal with tax reforms. Malcolm Gillis classifies tax reforms based on six attributes, namely: 1) breadth of reform. For this attribute, tax reform conducted by focusing on reform of tax structure, or reform of tax administration, or reform of tax systems (focusing on structural and administrative reform); 2) scope of reform. In this attribute, tax reform can be carried out based on its scope, either a comprehensive 
reform by covering almost all the important source of revenue, or partial reform by only covering one or two important components of the tax system; 3) revenue goals; tax reforms are undertaken with the revenue reason, such as increasing tax revenue, improving tax ratio, replacing revenue (revenue neutral reform), or reducing revenue (revenue-decreasing reform); 4) equity goals; tax reforms are performed by fairness reason such as determining progressive tariff; 5) resource allocations goals. In this attribute, tax reform is performed by reducing taxes, so that resources can be allocated more efficiently; 6) Timing of reform. In this attribute, tax reforms is done by changing the whole tax policies simultaneously (contemporaneous reforms), or changing tax policies gradually (phased reforms), or changing the unrelated tax policies in a few years (successive reforms) (Gillis 1989). Referring these attributes, trend of tax reforms worldwide leads to the seven of main issues, namely: 1) position of tax authority in the government structure; 2) unification of tax and custom authority; 3 ) adding function of collection of social security contribution as a domain of tax authority; 4) adopting organizational structure based on function by combining segmentation and tax type approaches; 5) formation of data processing center; 6) establishing large tax payer unit; 7) improving tax administration, authority, and tax sharing (Gill 2003) .

Referring this classification, to achieve the optimal tax policy, tax reform should be started from the existing tax system and should be evolved from an initial situation of high reliance on production and trade taxes, to greater reliance on taxes on consumption and finally taxes on income. This theoretical scheme may be considered as useful guide for the design of tax reforms (Feldstein 1976; Mundle 1998).

\section{Related research: tax reforms in developing countries from the perspective of driving factors and elements ${ }^{1}$}

In developing countries, tax role towards state revenue is extremely large due to the high demand of country after independence from colonialism, financing war and reconstruction, public necessity for development, and government operations for the public services. Surprisingly, one of the first things to note is that almost $80 \%$ of state revenues depend on tax revenue. This dependence is also supported by lack of involvement of non-tax revenue sector. In term of tax type, it is noted that two thirds of tax revenue come from indirect taxes such as foreign trade taxes and customs. The existence of country's dependence on foreign loans leads to the quite large role and influence of international organizations and some developed countries in decisions relating to fiscal and economic.

It is interesting to see that problems in developing countries occur because of the complex tax system, narrow tax base, high tax compliance cost, injustice such as loopholes and exceptions, and high government intervention. The existence of state finance deficit due to the high debt, inflation, banking crisis and global economic crisis leads an impartial tax policy such as high tax rates and complex administrative procedures. Furthermore, the economic inequality, lack of tax education and knowledge, large tax burden, and inequity service lead to the high rate of non-compliance such as tax evasion and tax avoidance. In addition, the lack of integrity due to poor salary structure and law enforcement brings to moral hazard behaviors that tend to corrupt. On the other hand, the weak tax administration infrastructure induces the no maximum tax administration service. Implementation of tax administration tends to be unstable and inefficient owing to the high tax administration cost. The low personal income tax role occurs due to the unsupported tax administration system in which the government focus is still on enforcing tariff and improving tax regulation.

${ }^{1}$ Mansfield 1987; Burgess, Robin and Nicholas Stern 1993; Laurence, Henry 1999); Toye John 2000; Yoo, Ilho 2000; Islam, Azizul 2001; Bird, Richard M 2004. 
Referring these conditions, elements of tax reforms in developing countries related mainly to improve tax administration and tax revenue. In detail, the elements are separately namely modernizing the tax administration, simplifying tax laws, establishing an organizational structure based on the function, rationalizing tax rates by considering inflation and global economic crisis, determining the progressive tariff for income tax, accomplishing the efficiency and assessment program based on performance for tax administration, enlarging the indirect tax role such as the VAT by determining more precise and single tariff. Moreover, programs of intensifying tax revenue are carried out by introducing the self-assessment system and some new taxes, improving control functions, reducing loopholes, exemptions, various allowances, and changing tax tariffs. In addition, law enforcement program by improving tax sanction is directed to find a good balance between preventive measures that promote voluntary compliance \& corrective measure and to fight against tax fraud and tax evasion. The government also conducted actively integrity improvement program to grow public trust so that voluntary compliance will increase positively. As a result, these elements lead developing countries into the condition in which the capability of government to collect taxes or tax ratio at around 19 percent. (Mansfield 1987; Burgess, Robin and Nicholas Stern 1993; Laurence, Henry 1999); Toye John 2000; Yoo, Ilho 2000; Islam, Azizul 2001; Bird, Richard M 2004).

\section{RESULT AND DISCUSSION}

Based on literature review and research related to tax reforms in developing countries, then we explore tax reforms, specifically, in Indonesia as a part of developing countries and their effect on tax revenue and tax compliance. The findings and discussion can be elucidated as follows:

\section{Tax reforms in Indonesia}

Embryonic tax reform in Indonesia is formed in the late 1983. Tax reforms are then further developed and completed between 1983 and 2009 by aiming, namely: 1) revising legislation; 2) improving organizational structures, standard operation procedures, database and information technology systems; and 3) improving quality, competency, and integrity of tax officials (Pratama 2010, Arifin, 2016). Refer to Riphat et al (2017), implementation of tax reforms in Indonesia to realize these aims can be elaborated as follows:

\section{First phase of tax reforms $(1983,1994,1997)$}

Tax reforms in 1983, 1994, and 1997 are implemented as responses regarding both public and government demands through attempting to: 1 ) realizing a self-sufficient nation; 2) enhancing public participations; 3) simplifying kinds of taxes and tax liability; 4) overcoming the weaknesses and complexity of tax system; 5) pursuing equity for taxpayers; 6) developing national economy as an impact of world globalization; 7) stimulating more investment; 8) complying a comprehensive tax court necessity by a simple, fast and low cost process; 9) promoting a legal certainty; 10) simplifying Regional Tax Act; and 11) fulfilling a necessity of law in the sphere of tax collection, non-tax revenues, and tax on acquisition of land and buildings. The focuses of reforms are given predominantly to administrative and policy reform (Suhardjito 200;Bawazier 2011). The policy reforms through tax intensification and extensification are conducted with the main focus on determining progressive and simplified tariffs and reducing them by around 6.7\% in 1994. During these periods, the government also sets up non-taxable incomes and enhancing their amounts by around 80\%. In addition, the VAT and other consumption taxes and property taxes are reformed by expanding tax bases and introducing criminal sanction in these aspects (Uppal 2003; Directorate of Forming State Budget 2013). 
Furthermore, the administrative reforms are performed with the primary concentrate on namely: 1) changing the collection system from official assessment to self-assessment; 2) revising and amending tax provisions regard to General Provisions of Taxation, Income Tax Act, VAT other consumption taxes Act, Property Taxes Act, and Stamp Duty Act; 3) improving technical practice by adopting accounting practices, extending the taxpayers liability; and 4) determining the expired tax period from 5 years to 10 years. Furthermore, during this period, the Advisory Council Tax is determined as Tax Courts before a Tax Court Board formed. The government also introduces particularly new regulations with regard to the establishment of a board of tax dispute resolution, local taxes and levies, tax collection with coerce warrant, land and building title transfer duty, and non-tax revenue. The other important characteristics of these reforms are the changing commission of tax consideration into the board of resolving tax dispute, simplifying the local retribution into 3 groups (retribution of public, business, and licensing services), expanding tax surety of corporate taxpayers, and arranging the group of non-tax revenues including their rates. The self-and official-assessment are introduced for the Land and Building Title Transfer Duty and for Property Taxes respectively. In the similar occasion, the government also organizes the sharing income of Land and Building Title Transfer Duty from central to local governments (Suandy 2002; Poernomo 2004).

\section{Second phase of tax reform (2000)}

Tax reform in 2000 is undertaken as a response regarding both public and government demands through attempting to: 1) establishing a modern tax administration which is characterized by low tax rates and a broader tax base in order to realize a self-financing; 2) improving equity and convenience of taxpayers; 3) rising investments both foreign and domestic corporate, to simplify rights of taxpayers; and 4) equalizing welfare through local expenditure and revenue budget. The emphasis of reform is given predominantly to administrative and policy reform (Nasution 2003; Silaban 2010).

The policy reform by tax intensification and extensification is undergone with the principal focus on expanding tax subjects and objects and simplifying/exempting taxes, revising tariff structures by adding income ranges and reducing tariffs for individual taxpayer by around $8.3 \%$. The government also extends income ranges for corporate taxpayer and increasing non-taxable incomes by around $67 \%$. Self-assessment and incentives are given to pursue the consumer satisfaction. Reforming VAT other consumption taxes are accomplished by broadening tax bases and enhancing their rates. Furthermore, 5 (five) new legislations relating to general provisions of taxation, income tax, VAT other consumption taxes, tax collection by forced letter, and land and building title transfer duty are introduced as the second amendment of previous laws. In addition, new provisions regarding the taxable enterprise confirmation letter (Article 17c) and sanctions (Article 38 to 41A) are also enacted (Usman 2008; Directorate of State Budget 2013).

The administrative reform is conducted with the main concentrate on firstly, completing the concept of businessman, taxable entrepreneur, taxpayer identification number, tax assessment letter, tax assessments for returning the tax excess. The government also introduces the authority of directorate general of taxes to determine the taxpayer registration and notification letter for undelivered annual tax return. Secondly, administrative penalties on the unreported or late annual and monthly tax return become 25,000-50,000 and 50,000-100,000 respectively, including intensifying obviously sanctions for past due payments. The government is also accomplished reforms engaged in collecting by forced letters, enhancing the business value of equipment, enlarging the types of goods excluded from the auction, and affirming the amount of billing cost and the insurer taxes (commissioner, shareholders, owner of capital). Thirdly, supervision system is reformed by changing the tax structure 
of judiciary to be an independent legal entity under the Supreme Court. The Fiscal Policy Board of Ministry of Finance is also established to formulate tax regulations. Finally, the government modernizes the tax administration both in terms of software, hardware, and human-ware based on information and technology.

These activities are marked by namely: 1) improving organizational structure according to the function; 2) simplifying and completing operating systems; 3) disseminating tax information; 4) delivering more effectively and efficiently system in sphere of audit, billing, payment, service and supervision; and 5) delivering supportable and quality procurements of infrastructure. Since this year, large and small taxpayer offices were built that followed by implementing e-payment, e-SPT, e-registration, e-filing and DGT Information Systems. The government also reforms ethics, morale, and integrity in order to achieve professional and qualified human resources by strict selection, placing staff based on capacity and capability, reorganization, regeneration, training and self-capacity development program (Erata 2004; Sahdani2005; Brondolo 2008).

\section{Third phase of tax reforms $(2004,2005,2007,2009)$}

Tax reforms in 2004, 2005, 2007 and 2009 are implemented as responses regarding both public and government demands through attempting to: 1) increasing the level of tax compliance and efficiency of tax collection in supporting the government revenue; 2) improving services, legal and justice certainty, competitiveness of investment and development of small and medium enterprises; 3) adjusting socioeconomic development and information technology; 4) balancing right and liabilities; 5) implementing accountable/consistent self-assessment system; and 6) improving professionalism of tax officials. The concentrates of reforms are given predominantly to administrative and policy reform (Setiyaji and Hidayat 2005; Kiswara 2006).

The policy reforms through tax intensification and extensification are undertaken with the primary focus on enhancing the non-taxable income in 2004, 2005, and 2007 by around $150 \%, 8 \%$ and $18 \%$ respectively. Then, the government enlarges income ranges and decreases tariffs for individual taxpayer by around 5\% in order to reduce the tax burden of low income earners and increased the burden on those in the high income brackets. The norm calculation for individual taxpayers is used for gross income about 4.8 billion. Bank Indonesia surplus is determined as the object of income tax.

Furthermore, the government introduces the definition of a permanent establishment (including a warehouse and an electronic agent) and increases administrative sanctions for income tax of article 21,22 , and 23 regarding to the non-taxpayer identification number. Then, during these periods, the government gives some tax incentives such as lowering income tax rate by around $50 \%$ for domestic corporate taxpayers who have turnovers until 30 billion IDR, expanding deductible costs for donations and scholarships and $0 \%$ tariff for export on intangible taxable services and goods. The government extendsthe tax bases and tax rates for income tax including VAT other consumption taxes. Especially for sales tax on luxury goods, the government raises its rates at from $75 \%$ to $200 \%$ in pursuing improvement of income distribution. In addition, the government also introduces penalties associated to late/undelivered the annual tax return and revised the Income Tax Act and General Provisions of Taxation as the third amendment with emphasis on both eliminating irregularities and providing strong support for the modernizing tax administration (Ikhsan 2005; Directorate of Forming State Budget 2013).

The administrative reforms are performed with the principal concentrate on determining the administrative process in transferring property taxes from the central to local government as a form 
of implementation of regional autonomy and fiscal decentralization. In the similar occasion, the government also introduces The Project for Indonesia tax Administration Reform (PINTAR) for period until 2013 as part of modernizing tax administration. This program involves four components including improvement of system and core business processes, management of human resources, tax compliance, and change management (Pandiangan2008;DGT2009). And then the reforms also formulated the amnesty mechanism in order to increase the compliance of taxpayers.

\section{Tax reforms in Vietnam}

Since economic reform in 1986, called "Doi Moi”, the Vietnam tax system has gone through three fundamental phases to improve its competitiveness. The first phase of reform was implemented in earlier 1990s with the introduction of a unified tax system that applied for both private sector and public sector. The second phase of reform was initiated in late 1990s in the context that Vietnam signed ASEAN Trade Freedom Agreement (AFTA) and was preparing for negotiations on World Trade Organization (WTO) access with the introduction of modern taxes such as value-added tax and corporate income tax. The third phase of tax reform program till 2010 was implemented with a general objective of building a comprehensive and appropriate tax system in association with modernization of tax administration. Refer to Norregaard et al. (2015), Shukla et al. (2011), Willenbockel, Dirk (2011), Duc, Nguyen Cao \& Go Yamada (2009), Chan, Nguyen, Madanmohan Ghosh, and John Whally, (1999); Quang, Ngo Dinh \& Nguyen Tien Dung (1997), and Mundle, Sudipto (1988), the application of tax reforms in Vietnam could be described as follow:

\section{First phase of tax reform (1990-1995)}

It was implemented in earlier 1990s with a result of introduction of a unified tax system, including 9 important taxes to replace the different types of taxes applied for state-owned sector, private-owned industry and trade sector and the agriculture sector with over $70 \%$ of population nationwide. Turnover tax, profit tax and export-import tax were very important and played an important role in this reform stage.

In detail, the government introduces nine important tax legislations involving 1) import and export duties, effective from January 1, 1988, consisting of 36 tax rates; 2) turnover tax, effective from October 1990, consisting of 11 tax rates, ranging from $0.5 \%$ to $40 \%$; 3) law on special consumption tax, effective from October 1990 with tax rates of from 20\% to 50\% imposed on cigarettes and alcoholic beverages, $50 \%$ on beers; 4) profit tax, effective from October 1990, consisting of 3 tax rates, namely $30 \%$ on the enterprises which produced materials for production; $40 \%$ on the enterprises produced consumer goods, processed products; $50 \%$ on trading and service enterprises, which were reduced to $25 \%, 35 \%$ and $45 \%$ respectively in 1993 . Then foreign invested enterprises paid profit tax at the lower rates in accordance with the Law on foreign direct investment; 5) law on agricultural land use tax, effective from January 1993; 6) law on the transfer of land use right tax, effective from January 1993; 7)ordinance on resource tax, effective from January 1990; 8) ordinance on income tax on high income earners, effective from April 1991; and 9) ordinance on housing tax, effective from October 1992, imposed on land, not on house. In addition, in this phase, the government also reforms the system of tax administration including established general department of taxation and determining that tax system is vertically organized from central to the local (province, district tax offices). 


\section{Second phase of tax reform (1997-2005)}

It was implemented in late 1990s in the context that Vietnam signed ASEAN Trade Freedom Agreement (AFTA) and was preparing to negotiate access to World Trade Organization (WTO) with the introduction of modern taxes, which are value-added tax and corporate income tax. This reform period expressed a great effort of the Vietnamese government in implementing the reform direction, reflected the economy's shift to market orientation. In this phase, the government introduced VAT and enterprise income tax including amending the regulations on import and export duties and on special consumption tax (excise tax) to ensure consistency in the tax system.

A tax system, which is considered to be relevant with the operation of a market-oriented economy, has been gradually established and applied uniformly to all economic sectors. In this context, the government developed some taxes, namely: 1) export and import duties; 2) Value added tax (VAT). For this tax, there are three tax rates covering $0 \%, 5 \%$ and $10 \%$ (prior to 2003, there were 4 tax rates, $0 \%, 5 \%, 10 \%$ and $20 \%$ ), in which zero rate are addressed for exported goods and services, $5 \%$ rate for essential goods and services, and $10 \%$ (standard tax rate) for other goods and services; 3) special consumption tax (SCT); 4) enterprise income tax (EIT). This tax is introduced in 1999 and amended in 2003. Scope of tax covers enterprises, household/business individuals, and partnerships. This tax is built by standard tax rate at $28 \%$ (prior to 2003, there were two different tax rates applied separately to domestic enterprises (32\%) and foreign invested enterprises (25\%); preferential tax rates: 10\%, 15\%, 20\% and 25\%; tax incentive (tax reduction \& exemption, loss carry-forward); investment encouragement areas (invested in remote and mountainous areas) and sectors (e.g. high-tech sector); and investment in industrial zones, special economic zones; 5) agricultural land use tax; 6) transfer of land use right tax; 7) personal income tax on high income earners (increased tax exemption threshold from 3 million VND to 5 million VND; 8) housing tax; 9) natural resources tax; and 10) adopted the ordinance on fees and charges.

Furthermore, total revenue from taxes, fees and charges had increased substantially, in which tax revenue in 1996-2000 increased by 2.3 times in compared with the revenue collected in 19911995. Then tax revenue in 2001-2005 increased by 2.0 times in compared with revenue collected in 1996-2000. However, tax system became more complicated (tax rates, tax incentives), was not comprehensive, non-synchronous, not including all taxable objectives and sources of revenue in market economy, not really transparent, unequal, thus not suitable to the international common practice. This is evidenced by too much VAT exempted goods and services (26 categories of goods and services) and lack of adequate VAT threshold. Therefore, the government continued to conduct third phase of tax reform.

\section{Third phase of tax reform (2006-2010)}

Objectives of reforms cover 1) being an importance role for macroeconomic management; 2) encourage domestic production, investment and export activities; 3) ensure adequate level of revenue collection for the State budget; 4) in line with the process of international economic integration; 5) ensure fairness and equity; and 6) contribute to the process of tax administration reform. In this phase, the government eliminated and simplified some procedures and tax rules such as amending VAT legislation in 2008 by opening tax base, reducing the number of goods and services which are VAT exempted; reforming tax tariff structure (Expanding scope of 10\%, narrowing scope of 5\%); and calculation method (Set the requirement to input VAT deduction as to make payments through the banking system) including applying VAT thresholds.

Furthermore, amending special consumption tax legislation (SCT) in 2005 and 2008 resulted 
reforming tax rates in term of reduces taxes on beer and alcohol to open the market due to the commitment of joining WTO. Then reforms were continued by reviewing special consumption tax reductions and exemption including applying non-discrimination principle between domestic produced goods and imported goods. Next, the application of SCT is expanded for airplanes, yachts of personal use. Reforming CIT was conducted in 2008 by reducing tax rate from $28 \%$ to $25 \%$ and simplifying tax incentives including narrowing the scope of tax exemptions \& reductions and applying a single corporate income tax regime for all economic sectors.

In side of personal income tax, reforming PIT was carried out in 2007 by introducing Personal income tax Law (effective from 2009), expanding tax base and taxpayers, and reassigning tax rates. Introducing Law on natural resource tax was realized in 2009 by changing regulations on dutiable and tax rates to increase revenue and help protect natural resources. Next, introducing Law on nonagricultural land use tax in 2010 was performed through setting the tax calculation method according to the percentage of land's price, increases taxes on land used for residing in urban areas, decrease taxes on rural areas' resident land. In addition, introducing environment protection tax was implemented in 2010 by a new tax that targets products whose use is harmful to the environment. This will both create revenue and help change the behaviors of producers and consumers. Furthermore, tax administration reform was applied by modernization tax administration system covering organization, personnel, and technology. In this context, Vietnam developed e-tax to provide easiness for taxpayers to submit their annual tax returns by online.Finally, self-assessment mechanism was realized through tax education and dissemination of information.

\subsection{Lesson from tax reforms in Indonesia}

Tax reforms in Indonesia were carried out as a response of both public and government demands, mainly to achieve a self-sufficient nation. Tax reforms were conducted in the three phases started in 1983 by changing tax collection system from official assessment into self-assessment. Furthermore, reforms were continued by undertaking many innovations in side of policy and administration including tax amnesty in order to increase the government income in the side of taxation (in the sort time) and to enlarge tax compliance in the long term.

In the side of reform of policy, tax reforms succeeded to reduce tax rates from $5 \%$ to $8.3 \%$ and increasing non-taxable income from $8 \%$ to $150 \%$. Then, reforming VAT and other consumption taxes were realized by expanding tax bases and fostering tax rates for luxury goods tax from $75 \%$ to a maximum of $200 \%$. Moreover, reforming property taxes were embodied by expanding tax bases and transferring their management from central to local government.

Tax reforms also succeeded to make several innovations in the field of administration. They were manifested by reforming tax collection system by changing official to self-assessment, reforming tax policy by amending and introducing new laws, reforming technical practice of taxation by adopting accounting system, reforming administration by determining expired tax period, advancing tax sanction, introducing tax letters and rearranging tax management, reforming control system by changing structure of tax judiciary and introducing laws of tax court, modernizing tax administration both in terms of software, hardware, and human-ware based on information and technology, and reforming system and management of human resources and information and communication technology by introducing PINTAR program.

As a result, the tax reforms implemented more than three decades have contributed to increase the tax revenue on average at 21 percent. Specifically, tax reforms succeeded in enhancing the overall tax revenue and tax revenue mix related to performance of individual taxes. At the same time, 
tax reforms had meaningful contribution to enhance registered taxpayers. In fact, currently, tax reforms leaved the 77 percent of potency taxpayers.

Overall, the lessons learnt from the practical tax reform in Indonesia, tax reform has contributed significantly to improve the government income relied on almost 80 percent from taxes. The role of tax reforms are be important because they succeed to increase overall tax revenue and performance individual taxes. By this income, government allocated at around 38 percent in 2014 for social expenditure (health care, education, culture, and others). Although, there is no specific survey to measure the satisfaction of taxpayers toward the implementation of tax reforms in Indonesia, the reforms provide the considerable room in increasing tax revenue. This is because the ability of tax reform to increase registered taxpayers and the capability Indonesian people in economic if we refer to the gross domestic product (GDP) in Indonesia.

\subsection{Lesson form tax reforms in Vietnam}

Vietnam's taxation system has undergone fundamental reforms since 1990s. Tax reform programs of the 2000- 2010 period were released successfully, putting in place a tax system that met the requirements of a market economy and necessary legal conditions for accession to the World Trade Organization. Tax structure has been modernized, moving the Personal Income Tax system from a taxation of high-income earners to the introduction of a universal income tax, and the adoption of a Natural Resource Tax Law to promote their efficient use and to ensure social equality in exploiting and using the natural resources of the country (World Bank 2011). Tax policy has taken into account regional and global trends and the need to facilitate tax compliance of the rapidly growing private sector. Tax revenues in the 2006-2010 achieved doubled point compared the previous five-year period and represented at around 23 percent of gross domestic product (GDP).

Vietnam has been successful in tax reform in the period of 2006 - 2010. New taxes may instead of tax reduction by WTO commitments. In this context, the government met the requirements to facilitate the accession of Vietnam into the WTO by amending the law on export and import duties in 2005, amending the law on value added tax and the law on special consumption tax (by removing the provisions which were discriminated between locally produced goods and imported goods, and reforming fees and charges provisions related to imported good.

Furthermore, Vietnam succeeded to adopt the law on personal income tax in 2007, to amend the law on value added tax in 2008 through reforming the tax rate structure, adopting VAT threshold, and narrowing the list of VAT exempted goods and services. In the side of enterprise income tax, the government amended the law by reducing the standard tax rate to 25 percent, allowing the enterprise to use a maximum of 10 percent of their taxable income to establish research and development fund, reviewing tax incentive regime, and abolishing preferential tax rate of 15 percent (the new law was expected to have only two preferential tax rates of 10 percent and 20 percent) including simplifying the durations of tax exemption and reduction. In the side of administration, Vietnam succeeded to modernize tax administration focusing on organization, personnel, and technologyincluding implementation self-assessment by dissemination and education. As a result, based on the survey of VCCL in 2016, 75 percents of taxpayers in Vietnam stated satisfaction toward tax reforms applied by government.

Overall, the lessons learnt from the practical tax reform in Vietnam, tax reforms have contributed significantly to the process of economic reform in Vietnam. Tax reforms succeed to enlarge revenue from taxes, so that they become an important source for the State budget. As an impact, tax reforms afford making the government to have ability in increasing investment from the state budget and 
paying foreign debt. Interestingly, by tax reforms, the government has capability to meet social expenditure requirements (health care, education, culture, and others). In this context, almost 55 percent of government income is allocated for public interest. Finally, tax reform always encounters a lot of obstacles from the real world as well as opinions of many interested groups in the society, even in the class of people who are policy makers.

\section{E. CONCLUSION}

The objective of this study was to investigate the role of tax reforms in Indonesia and in Vietnam by identifying kind of innovations and the insight learned from both reforms to seek a key success factor in tax ratio. As a result, I found three interesting points. Firstly, tax reforms in Indonesia and Vietnam have similarities, in which they are focus on reform of policy (by and large: broadening the tax base and reducing tax rates) on the one hand and the reform of tax administration on the other hand. In the side of administration, they amend the laws and introduce new taxes. They also modernize tax administration involving organization, personal and technology. Secondly, for both countries, tax reforms have contributed to increase tax revenue. As consequence, income from this sector has the important role for state budget. Finally, both countries highlight the role of tax reforms to enlarge the function of government in allocating state budget for social expenditure.

From all perspectives, I conclude that tax reforms in Indonesia and Vietnam have the similarities in implementation and in the role for improving state budget. Based on the result of reforms, I underscore the success of Vietnam to improve tax ratio because of the appreciation of government for society as taxpayers. It is evidenced by the large allocation of government income for social expenditure compared by Indonesia. It means that Vietnam government provides more feedback and benefit for citizens from tax payments. Therefore, this condition produces the easiness of government to collect taxes from society. This is a key success factor of Vietnam, so that it is not surprisingly if Vietnam's tax ratio is higher than Indonesia.

In a short, Indonesia should learn from Vietnam in this context. As recommendation, the government should find an appropriate wayto appreciate taxpayers as a feedback from tax payment in order to improve tax compliance. Tax compliance is very important because success or not the process of collecting taxes depends on this issue.

\section{REFERENCES}

Abimanyu, Anggito. (2003). Reformasi Perpajakan. Jakarta: Salemba Empat.

Alm, James. (1996). What is an optimal tax system. National Tax Journal 49.1: 117-133.

Arifin, Gusfahmi. (2016). Perlunya Reformasi Pajak. Website Direktorat Jenderal Pajak.

Bawazier, Fuad. (2011). Tax Reform in Indonesia. Journal of Legislation of Indonesia, Vol.8, No.1.

Bernardi, Luigi. (2005). Tax systems and tax reforms in new EU members. Vol. 51. Routledge.

Bird, Richard M. (2004). Administrative Dimensions of Tax Reform. Asia-Pacific Tax Bulletin, 134-150.

Brondolo, Jhon, Carlos Silvani, Eric Le Borgne, and Frank Bosch. (2008). Tax Administration Reform and Fiscal Adjustment: The Case of Indonesia (2001-2007). Journal of Economics. 
Burgess, Robin, and Nicholas Stern. (1993). Taxation and development. Journal of Economic Literature 31.2: 762-830.

Chan, Nguyen, Madanmohan Ghosh, and John Whally. (1999). Evaluating Tax Reform in Vietnam Using Genera Equilibrum Methods. Viet-Jpm.Wpd.

Directorate General of Taxation. (2009). Annual Report, Ministry of Finance Jakarta.

Directorate of Forming State Budget. (2013). The Basics of Practice of Forming State Budget in Indonesia. Directorate General of Budget, Ministry of Finance.

Duc, Nguyen Cao and Go Yamaha. (2009). Tax System Reforms in Japan: Lesson for Vietnam. Final Report. Nikkei (Nihon Keizai Shimbun), Inc. Japan Center for Economic Research (JCER), Tokyo Japan.

Erata, I Made Gde. (2004). “Modernization of Taxation,” One Day Seminar, Revision of Laws of Tax General Provisions, Income tax and Value Added Tax, Multi Utama Development Centre.

Feldstein, M. (1976). On The Theory Of Tax Reform. Journal of Public Economics 6, 77104.

Gill, Jit. B.S. (2003). The Nuts and Bolts of Revenues Administration Reform.

Gillis, Malcolm. (1989). Tax Reform in Developing Countries. Duke University Center for International Development. Duke University Press: Durham.

Ikhsan, Mohamad, Ledi Triadi, Syarif Syahrial. (2005). The New Indonesian Tax Reform Initiatives: Mediating Two Competing Proposal, Jakarta.

IMF Report. (1996 - 2014).

Islam, Azizul. Issues in Tax Reforms (2001). Asia-Pacific Development Journal, Vol.8, No.1: 112.

Kiswara, Endang. (2006). Article of Tax Reform in 2006 and Discourse of Ideal Public Policy in Good Governance Era, Congress ISEI XVI in Manado.

Laurence, Henry. (1999). Financial System Reform and the Currency Crisis in East Asia. Asian Survey. Vol.39 No.2: 348-373.

Mansfield, Charles Y. (1987). Tax Administration in Developing Countries, an Economic Perspective. IMF Working Paper 87/42 (Washington: International Monetary Fund).

Mas’oed, M. (1994). Negara, Kapital, dan Demokrasi. Yogyakarta: Liberty.

McLure, C.E. Jr. (1990). Appraising Tax Reform, In M. Boskin and C.E. McLure, eds., World Tax Reform Case Studies from Developed and Developing Countries, San Francisco: ICS Press. Ministry of Finance, 2012. State Budget, Monetary Development, and Finance Agencies.

Mundle, S. (1998). Tax reforms in Vietnam: A selective Analysis. High Level Symposium on Tax Reforms. Hanoi.

Mundle, Sudipto. (1988). Tax Reform in Vietnam: A Selective Analysis. Program Department West.

Nasucha, Chaizi. (2004). Reform of Public Administration, Theory and Practice: Published by PT Gramedia Widiasarana, Indonesia. 
Nasution, ChairudinSyah. (2003). Analysis of Potency and Revenue Growth of Income tax in Indonesia for Period of 1990-2000. Study of Finance and Economy, Vol.7, No.2.

Norregaard et al. (2015). Tax Reform in Vietnam Issues for 2011-2015. Fiscal Affairs Department.

Pandiangan, Liberti. (2008). Modernization and Reform of Tax Service Based on New Laws. PT. Elex Media Komputindo, Gramedia Group, Jakarta.

Perry, Guillermo, and John Whalley. (1995). Tax Reform and Structural Change. London: Macmillan.

Poernomo, Hadi. (2004). Reform of Tax Administration in Fiscal Policy: Thingking, Concept, and Implementation. Kompas.

Pratama, Wahyudi. (2010). Development of Taxation in Indonesia.

Quang, Ngo Dinh and Nguyen Tien Dung. (1997). Tax Reform in Vietnam. Vietnam Socio-Economic Development, No.10 Summer.

Riphat, Singgih, Mohamad Nasir \& Purwoko. (2017). Penerimaan Perpajakan: Merespon Pencapaian dan Tantangan Perubahan Ekonomi.

Rizal, Yond. (2008). Lessons from Indonesian Tax Administration Reform Phase 1 (20012008): Does Good Governance Matter? Limit of Good Governance in Developing Countries.

Sahdani, Djazoeli. (2005). Toward Good Governance Through Modernizing Tax. Business of Indonesia.

Setiyaji, Gunawan and Hidayat Amir. (2005). Evaluation of Performance of Indonesia's Tax System. Journal of Economy, University of Indonusa EsaUnggul-Jakarta.

Shome, P. (2006). The control of tax evasion and the role of tax administration. In Luigi Bernardi, A. F. A. P. S. (Ed.) Tax Systems and Tax Reforms in South and East Asia. Oxon, Routledge.

Shukla et al. (2011). Tax reform in Vietnam: Toward a More Efficient and Equitable System. Poverty Reduction and Economic Management Unit East Asia and Pasific Region. The World Bank.

Silaban, Reinhard. (2010). The influence of Tax Reform in1983, 1994, dan 2000 Toward Tax Revenue. Thesis of University of Indonesia.

Suandy, Erly. (2002). Tax Law. Jakarta: Salemba Empat.

Suhardjito. (2006). Tax Reform in order to Improve Tax Compliance, Good Governance Including Self-Sufficient Nation. Forum of Management, Vol.13, No.03.

Tanzi, V. (1992). Introduction, in V. Tanzi, ed., Fiscal Policies in Economies in Transition, Fiscal Affairs Department, International Monetary Fund, Washington, D.C. Uppal, J.S, 2003. Tax Reform in Indonesia. Gajah Mada University Press.

Toye, John. (2000). Fiscal Crisis and Fiscal Reform in Developing Countries. Cambridge Journal of Economics: 24, 21-24.

Uppal, J.S. (2003). Tax Reform in Indonesia. Gajah Mada University Press.

Usman, Marzuki. (2008). Fiscal Policy: Thinking, Concept, and Implementation. 
Willenbockel, Dirk. (2011). Environmental Tax Reform in Vietnam. Institute of Development Studies. University of Sussex. Brighton BN1 9 RE-UK.

Yoo, Ilho. (2000). Experience with Tax Reform in the Republic of Korea. Asia-Pacific Development Journal: Vol. 7, No. 2, 75-104. 